\title{
Diversity Through Interaction: An Interview Forum
}

\section{Matthew W. Turner}

Toyo University

\section{Matthew Y. Schaefer \\ Tokyo International University}

\section{Robert J. Lowe}

Tokyo Kasei University

\section{Mehrasa Alizadeh}

\section{Osaka University}

\section{Dat Bao}

\section{Monash University}

\section{Judith B. O'Loughlin}

\section{Language Matters Education Consultants, LLC}

\section{Reference Data:}

Turner, M. W., Schaefer, M. Y., Lowe, R. J., Alizadeh, M., Bao, D., \& O’Loughlin, J. B. (2019). Diversity through interaction: An interview forum. In P. Clements, A. Krause, \& P. Bennett (Eds.), Diversity and inclusion. Tokyo: JALT.
This paper accompanies an explorative and interactive forum that featured interviews with invited conference speakers Mehrasa Alizadeh, Dat Bao, and Judith B. O'Loughlin, in the presence of a live audience. Each interviewee was selected so that speakers from a variety of disciplinary backgrounds within applied linguistics could be represented, with the interviews designed to explore diverse interests so as to establish commonalities, promote mutual understanding, and create a space for new insights to emerge between practitioners in the field. The paper opens with a description of the aims, rationale, and format of the session, followed by reflective accounts of each of the interview exchanges. It concludes by addressing the themes and insights that emerged during this interactive session, as a way to evaluate the potential of forums with a dialogic emphasis.

このフォーラムは、三人の招待されたスピーカー(Mehrasa Alizadeh, Dat Bao, and Judith B. O'Loughlin)のインタビューを 取り上げたものでる。始めにそれぞれのスピーカーをインタビューし、その後、三人で討論しもらった。その結果が研究者たち の助けとなるよう、応用言語学のそれぞれの違った専門分野の専門家がお互いから何を学ぶか、共通点は何かを観察した。 本論文は、このフォーラムの全員の参加者の意見を反映したものである。

iversity Through Interaction: An Interview Forum was conceived of with a number of aims. This section will outline some of the main rationales driving the session as well as explain the reasoning for the experimental approach taken.

Applied linguistics (AL) is a diverse field, with scholars tending to focus on a particular area of specialization, often leading to a limited understanding of work being carried out in other subdisciplines (Medgyes, 2017). An aim of this forum was to bring together scholars from divergent disciplinary backgrounds and explore commonalities between their areas of research specialization. It was hoped that by gathering researchers from a variety of disciplinary and personal backgrounds it would be possible to generate new understandings across the field.

Underlying our attempts to bring together scholars was the need to create more immediate dialogue. In AL, dialogues between scholars are conducted in scholarly papers and books over years and sometimes decades (see Clarke, 1994). This forum was devised to reduce this so-called "interaction at a distance" (Maley, 2015, p. 3) and cultivate instances of real-time exchange. Although interdisciplinary work has been central to 
the social sciences for decades (see Choi \& Richards, 2017), this "real-time" approach to scholarly interaction is relatively new. Approaches to dialogue at conferences have either focused on discussing previously presented ideas (Graham \& Kormanik, 2004) or attempting to disrupt established norms within a field (Carducci, Kuntz, Gildersleeve, \& Pasque, 2011). In contrast, this forum was aimed at fostering a sense of interdisciplinarity understanding.

In assembling a group of researchers and encouraging dialogue, it was hoped that our forum would act as a site for new ideas to emerge. Dialogic exchanges, from a sociocultural perspective, are seen as being intrinsic to growth, transformation, and development (Wells, 1999). Therefore, a further aim of our forum was to put forward a co-creative mode of knowledge transmission and to counter didactive formats commonly seen at academic conferences (see de Vries \& Pieters, 2007). As such, the concern of the forum was not the presentation of practical or theoretical projects but rather a focus on new explorations among the forum's participants.

The forum was delivered in conjunction with the authors' ongoing podcasting project (see Lowe, Schaefer, \& Turner, 2017). We have been exploring podcasting as a form of continuing professional development (CPD), in which we come together to reflect on topics related to the profession. In one particular aspect of the podcasting project, we connect with other scholars across the AL community in order to interactively reinforce and expand our understandings of others' work. As such, this forum was aimed at furthering our understandings of other people's ideas as well as giving the interviewee participants the chance to revisit and reflect on their own work and beliefs.

\section{The Forum's Format}

This forum replicated a format developed for the Global Educators, Local Connection forum detailed in Schaefer, Turner, and Lowe (2018). The forums were loosely inspired by "dialogue events" undertaken in the sciences (see Lehr et al., 2007). Dialogue events are face-to-face gatherings of scientists, members of the public, and policy-makers, organised to support two-way interactive engagement of scientific knowledge and research. In the context of JALT, this forum revives calls previously made by Barfield and Smith (1999) to generate different interaction spaces and sensory modalities at conferences as well as more participatory format mediums.

First, three interviews were conducted between invited conference speakers and the forum facilitators, followed by a panel discussion involving the participants (although due to a scheduling conflict, only two were present for this stage of the forum). Before the forum, each of the organizers devised a series of questions to guide the interviews (see Appendix A). Questions were written based on the published output of the interviewees, with further questions added upon attending their presentations and workshops. The organizers gave the interviewees the chance to reflect on the questions beforehand. The interview interactions were semistructured in nature, in that there was a level of flexibility with regard to how and what questions were asked as well as to follow-up questions and comments (see Mann, 2016).

Three interviewees were chosen by the presenters to broadly reflect the overarching conference themes of diversity and inclusion. These decisions were influenced by hopes to include female educators, invite language educators from underrepresented parts of the world, and bring together scholars from different areas of research specialization. The following speakers accepted the invitation to participate:

- Mehrasa Alizadeh-A PhD candidate (now graduate) from Osaka University, with interests in computer assisted language learning and mixed, augmented, and virtual realities in education;

- Dat Bao-A senior lecturer at Monash University, researching creative pedagogy and intercultural education in language learning; and

- Judith B. O'Loughlin-An independent education consultant in the U.S.A., concerned with resilience and differentiated instruction with ESL learners.

The final part of the forum involved the interviewees coming together to reflect on each other's interviews as well as expand and build on ideas with one another. All interview sessions, as well as the interviewee discussion, were recorded and subsequently released as podcast episodes (see Appendix B).

\section{The Function of This Paper}

Unlike traditional conference proceedings papers that record the ideas from an oral presentation, this paper is a reflective report of our session. The forum had an unplanned quality to it, allowing for new discoveries to be made in situ. Therefore, this paper should be understood as a companion piece to the forum and is one part of a wider mixed-media project, along with the audio podcasts. As discussed earlier, it is hoped that this paper exemplifies the collaborative developments in understanding what occurred among the writers and the forum participants. 
Interview Accounts

The following sections provide accounts of the three forum interviews. Unlike the previous forum paper (Schaefer et al., 2018), which presented abridged retellings of each interview, the following three sections will take a more reflective approach. Each section will open with each interviewer setting out their aims and what they hoped to discover through their questions. These will then be followed by reflections by both interviewers and interviewees. Time references will be provided at key points to the relevant sections of the accompanying podcast episodes, in order to supplement the mixed-media approach.

\section{Interview 1: Mehrasa Alizadeh (Matthew Y. Schaefer)}

I chose to interview Mehrasa Alizadeh because of my unfamiliarity with her areas of research interest: computer-assisted language learning (CALL) and mixed, augmented, and virtual realities (MAVR). I have almost no experience with MAVR for recreational or professional uses. A second reason was Mehrasa's nationality. Having never visited Iran, and with only a very general awareness of the country's ELT research, I was curious to learn more about Mehrasa's academic and professional background. Both of my reasons, therefore, were in keeping with the theme of exploring diversity, in this case between interviewer and interviewee. In preparing my interview questions, I referred to Alizadeh, Mehran, Koguchi, and Takemura (2017) and Hawkinson, Mehran, and Alizadeh (2017).

My first planned question was to ask Mehrasa for a summary of her career history, with the intention of following up with enquiries about the differences between language teaching in Iran and Japan. I was also curious to discover what led to her moving from one country to the other and how her career trajectory had guided her to the use of technology in language learning. The next few questions were about CALL and MAVR to provide a general context for both myself and audience members. Next, to connect Mehrasa's area of interest with my own, I asked about the link between MAVR and teachers' professional development. Finally, aware that she would be unable to hear Dat Bao's interview, I wanted to finish with a question seeking a connection between technology and creativity in the classroom.

The Interviewer's Reflection

Mehrasa began by talking about her journey from language learner to language teacher and from Iran to Japan [2:12-4:22]. Both of these made me aware of further aspects of diversity that I had not previously considered. First, although I have been a learner of languages, I feel that this has had little (conscious) impact on my identity as a language teacher, but for Mehrasa there was a very clear progression from one to the other. She spoke about how her initial attempts at enrolling in an overseas $\mathrm{PhD}$ program were unsuccessful due to the difficulties of being an Iranian seeking study in North America. I have been fortunate never to have faced this kind of issue, which was a reminder of the academic and professional challenges that some language teachers face due to political factors.

Several of Mehrasa's answers to my questions helped raise my awareness of not only CALL and MAVR in language learning, but also issues beyond the use of technology in the classroom. One example was when she described the use of VR videos for teacher education [16:45-18:21], explaining how a teacher trainer she knew of used 360-degree immersive recordings of preservice teachers' practice lessons to help them reflect on what they had done (see Driver, 2018). As a teacher trainer involved in lesson observations, I found this fascinating and could imagine a future in which this became commonplace. Another example was when Mehrasa talked about collaborating with professors from a university's computer science department, who had no background in language education [15:20-16:25]. This made her realize that many language teachers rarely communicate with academics outside of their own field but, having done so, she now feels a responsibility to act as a bridge between the two disciplines of technology and language teaching. I reflected that, although a goal of this forum was to encourage communication among practitioners within AL, it may also be of benefit to seek connections with those outside of language education altogether. In this sense, Mehrasa's integration of technology in the language classroom may be seen as a successful model.

\section{The Interviewee's Reflection}

For me, it has been a great way to think beyond my field of interest and to consider various perspectives and different areas of research within ELT. I had previously used podcasts only for learning foreign languages, but after learning more about the forum facilitators' podcast, $\mathrm{I}$ have come to realize that podcasting has great value for professional development as well, particularly for busy teachers who may not have time to sit down and read an article or interview. I would like to extend my thanks to the forum organizers for this magnificent initiative, and I hope that in the future we will be witnessing more of these conversations going on among academics at conferences, webinars, and other events. 
Interview 2: Dat Bao (Matthew W. Turner)

The second interview in our forum was conducted with Dat Bao. In forming my questions, I familiarized myself with two of Dat's books: Understanding Silence and Reticence: Ways of Participating in Second Language Acquisition (2014) and Poetry for Education: Classroom Ideas That Inspire Creative Thinking (2017). As such, the focus of the interaction was principally oriented around the topics of silence and creativity, with the majority of questions aimed at finding out more about Dat's interests in creativity in education. A further aim of the interview was to explore what the potential connections could be between creativity and silence.

For the initial part of the dialogue, I wanted to ask Dat more about creativity and imagination in education and what benefits could be brought through heightened selfexpression. Given that we would be talking about creativity, I asked Dat to share some poetry with the audience, having arranged this in advance. In keeping with the rationale of our forum, I also wanted to learn more about one of Dat's conference presentations. The presentation was about a group of Japanese learners studying in Australia, and I was keen to find out how creativity played a role in their learning efforts and social embeddedness.

The focus of the interview then progressed to silence and reticence in language learning classes. As the theme of the conference asked participants to consider terms like diversity and inclusion, I was interested to know about the silence phenomenon, its geographical and multifaceted nature, and if teachers were aware of this. The interview culminated in a reflection on the possible links between silence and creativity in language learning classes.

\section{The Interviewer's Reflection}

At the start of the interview [2:11-3:10], Dat took us on a journey through all the countries he had lived, studied, and worked in. I felt amazed by the uniqueness of his personal and academic path and hadn't fully considered how this would characterize his research. Through my preparation, I had learned that one of Dat's areas of enquiry was the phenomenon of silence, but I hadn't known the reasons and stories behind this. This became clearer at the start of our interaction when Dat remarked on the differences across cultures in the amount that people talk and the amount that people keep silent. Dat described how silence is used in education, and having never considered that silence may have a utility in classrooms, I was interested to find out about these roles. Later in the interview [19:50-21:58], Dat talked about perceptions of a hierarchical and dichotomous relationship between silence and talk, before questioning the starkness of these distinctions. During the exchange, I felt my beliefs being challenged, in that I had always considered talk and output to be a measurable indicator of learning, but Dat's studies on silence made me shift these beliefs. He explored how some students may prefer to learn through observation, rather than interaction, and that idea processing also takes place during quiet periods and not exclusively during verbal exchanges. Although I feel I already have some sensitivity towards silence in my classroom, my exchange with Dat has led me to think about how silence could be featured more in my classes and what effect it might have on quality of output, for example. Dat also used the term "inner dialogue" to explain silence along a continuum, which I feel is a much more accurate reflection of what is taking place internally. Prior to the interview, I had prepared a question for Dat that $\mathrm{I}$ had hoped would explore whether increased creativity in lessons would readily inspire a sense of willingness for more verbal interaction. However, as I came to ask the question, I felt that my earlier beliefs on this matter may have altered, rendering my question no longer reflective of my changes in understanding. Dat reiterated that silence can be unpacked as a spectrum, and so it may not be necessary to polarize silence and talk in this way, a comment I found myself agreeing with [22:1824:05].

The Interviewee's Reflection

The interview helped me think about connecting silence, creativity, and poetry-three of my favorite themes that I have written about but never really had the chance to connect.

I believe that much of creativity is about imagination. However, problems occur when students are too concerned about right and wrong, about rules and judgment. Such worry or fear restricts imagination as it narrows students' thinking autonomy. Poetry liberates the mind by allowing students to move away from judgment.

It is when students develop thinking beyond dichotomy and judgment that they are able to feel free to bring imagination power back to the mind. To be creative, students need to escape the kind of routine that prevents them from being playful. You cannot enjoy learning when someone is watching or assessing you!

Based on that philosophy, I have come to recommend a few ways to practice creativity:

- Make students curious and help them discover (such as to create an alternative ending of a story);

- Invite diverse responses without judgment (such as asking students what some methods may be to wash a gorilla so that it becomes clean); and 
- Challenge students both intellectually and emotionally (such as asking them how to save a cat that gets stranded on the roof of a house).

Freedom of expression, however, does not equal the freedom of talk. We might need to be aware that talking is not the only or best way to learn. Through research, I have learned that many students can develop knowledge and skills through observing rather than talking. Equipped with this understanding, we can come up with multidimensional activities that allow both forms of expression, speaking aloud and reflecting quietly, rather than holding on to those tasks that only promote talk or support highly verbal students.

\section{Interview 3: Judith B. O'Loughlin (Robert J. Lowe)}

The final interview in the forum was with Judith B. O'Loughlin, who previously gave a plenary presentation on the topic of resilience. I had recently read Capstick's (2018) "Resilience" and was aware that this concept was not on the minds of many language teachers. I therefore approached the interview with the aim of clarifying Judith's particular model of resilience, discussing how resilience could be important for English language learners and getting some response to the critical issues that $\mathrm{I}$ had come across.

The first part of the interview was aimed at building foundations for the discussion. This involved giving some background to Judith herself and her work on resilience and clarifying certain concepts that had been raised in her plenary talk. In particular, I was interested in hearing her descriptions of the "cycle of failure" and the "I have, I am, I can" model of resilience building discussed in her plenary, which focused on awareness raising of (a) the resources available to the student, (b) the personal characteristics of the student, and (c) the potential future goals the student can aim for (developed by Grotberg, 1995).

Finally, I had come across some critical literature that questioned the utility of the concept of resilience and the extent to which it promoted an individualist perspective, removing the burden of care from the government or the wider society. I was very interested to hear Judith's perspective on this.

\section{The Interviewer's Reflection}

During the interview, there were a few points that seemed particularly important. The first was Judith's description of the "cycle of failure" [5:32-7:46] in which students, unable or unwilling to show their difficulties or reach out for help, end up giving up gradually until they give up completely. This immediately made me think of some of my own past students who either suddenly disappeared (or gradually drifted) from my class. I wondered if these changes were the result of a cycle of failure that I had failed to recognize. Judith's explanation made me think about how an understanding of this process could have helped.

Second, my understanding of resilience before the interview was focused on students who had come from traumatic situations, such as refugees. I had little understanding of how this could apply to students from more "typical" backgrounds. Judith, referring to immigrants who had uninterrupted schooling and a family support structure, pointed out that even for these students there is a disconnect between their school and family lives [16:30-19:47]. The family lives of immigrants may be heavily influenced by their cultural background and, therefore, there is a cultural shift when they are at school. This made me wonder whether all students experience this cultural shift between home and school.

Finally, I was impressed by Judith's answer to my critical question regarding the individual focus of resilience. Judith denied that it placed responsibility on the individual and instead framed the process of resilience in terms of helping the students to recognize the resources available within their community and their family [19:48-21:40]. In other words, resilience seemed to be about not just who the students are but also what resources they have available to them, particularly in terms of the support structures of their surrounding community (mirroring the "I have" and "I am" elements of Judith's adopted model). Just as UNICEF highlights three levels of influence in resilience (the community, the family, and the individual), the model promoted by Judith promotes dialogue between the individual and the community and familial resources available to them.

The Interviewee's Reflection

Robert's questions helped me to clearly express my concerns for at-risk learners and their cycle of failure. Although l've written and presented about the topic of resilience as I continue to look for ways to help students, Robert's questions, my responses, and then his responses helped me both look within myself to what I hoped to share and then to articulate my personal feelings about building resilient learners. Beyond my personal feelings, I was able to express key ideas from research. The questions helped me focus on both research and personal experiences l've brought to the topic.

On a separate note, I connected the interview questions and my responses to my own personal experience living in Japan for 2 months, away from family, friends, and the lifestyle I had in the States. Understanding resilience on a personal level, my own 
experiences-and what I had to adjust to-helped me connect to English learner experiences, whether ESL or EFL. Thinking about how I developed my own resilience, persistence to learn to communicate as well as complete daily ordinary tasks, what I learned from this experience are important considerations for what I can bring to help others become resilient: the lens that helps us with how to look within and then look out.

\section{Emergent Themes}

Following the interview exchanges, Dat Bao and Judith B. O'Loughlin joined in conversation with one another; Mehrasa Alizadeh contributed her thoughts later by email. Participants were encouraged to reflect on the ideas expressed in each other's interviews and ask questions. This section is a reflection on three of the main themes that emerged from this interaction.

\section{Theme 1: Wait Time}

Judith commented on how silence relates to the notion of "wait time," that is, how long teachers wait for students to answer questions and how quiet "self-talk" can be a valuable moment of reflection for students before they speak [01:26-02:49]. Dat echoed this by suggesting silence is evidence of mental processing, although he also recognized that, when the whole class is waiting for a student answer, this may put more pressure on individual students. Dat suggested that the solution is to spend more class time on pair-work [3:02-4:30]. Judith added that it is important for teachers to model good wait-time practice as well as how to ask questions that elicit short answers and therefore require less mental processing [04:31-05:43]. Dat agreed and mentioned that pairs of students could also negotiate their own wait times to suit their communication styles [05:44-06:03]. Mehrasa added that it is important for teachers to consider the roots and functions of silence in their students and not always assume negative connotations [20:15-21:26].

\section{Theme 2: Singular or Plural?}

Dat reflected on Judith's "I have, I am, I can" model and imagined reframing it as a "We have, we are, we can" model in order to reduce the focus on the individual and instead consider how it could apply to networks and mutual support [08:41-10:01]. Judith responded by saying that for students who have been isolated and experienced interruption, it is important to begin with the "l" and then build to the "we" [10:3210:48]. Dat suggested allowing students to decide which they would prefer as a starting point, although Judith still felt that certain students need to have the strengths of the "I" before they can transition to the "we." Dat offered an alternative: Let those students team up with and learn from others first, before building their personal confidence when strong enough. Judith concluded by pointing out that the process could be "fluid" as a way to embrace diversity and to differentiate based on learner needs and learner profiles [10:49-11:51]

\section{Theme 3: Risks and Rewards of Technology in the Classroom}

Referencing Mehrasa's interview, Judith expressed her fascination at the idea of using VR and other technologies as a medium for helping the healing process for students who have experienced trauma. However, she also cautioned that care would be needed in such a process, along with the involvement of trained counselors or psychologists [12:0713:30]. Mehrasa pointed out how the use of technology in language education offers many opportunities for specialists in different fields to collaborate [18:29-18:51]. Judith pointed out another benefit: how technology can bring language education to students who may not otherwise have easy access to it [14:13-14:56]. Mehrasa mentioned the burgeoning field of apps that make language practice accessible to an increasingly wider range of teachers and students. Dat added that technology should always function alongside pedagogy rather than be adopted just for the sake of it [15:38-16:02]. Mehrasa responded that CALL and MAVR uses are still developing but fully agreed that it is paramount that practitioners take a pedagogically sound approach to how it is used [18:02-18:28]

\section{Evaluation of the Forum}

The format of this event allowed for an exploration of issues at a number of different levels. The initial interviews allowed space for participants to voice their beliefs and explain at some length their area of specialism, prompted by questions from interviewers. This allowed interviewers and audience members to gain understandings of each area of interest. These interviews also allowed the other participants to listen to and consider connections between their own area of work and those of the interviewee. The final discussion allowed space for these connections to be vocalized and explored, leading to the emergence of the three themes. These connections are interesting because they not only reflect discrete points from the interviews, but in some cases also represent expansions, extensions, and syntheses of ideas: for example, Dat Bao's shifting of the "I have, I am, I can" model from the singular to the plural and Judith O'Loughlin's considering the specific use of VR with victims of trauma. This occurred as the participants took on board the 
information presented and found subtle connections with their own work. The emergence of these themes is an indication of how commonalities, connections, and developments in thought can be identified, even between seemingly very dissimilar researchers (and people). The forum on which this paper is based is particularly notable for the fact that researchers and educators from extremely diverse backgrounds were chosen; yet even in this case it was possible to find connecting threads that tied together their specializations and opened up the potential for expanding their thoughts based on the assimilation of ideas from othe subdisciplines. One drawback of this forum, and perhaps an issue for future experiments of this type to consider, was the difficulty in securing all of the participants for each stage of the event. The fact that one participant had to contribute their thoughts after the fact necessitated some distance in thinking, removing some of the hoped-for immediacy of the interaction. Nevertheless, we suggest that more forums of this type, based on dialogic interaction and focused on foregrounding connections between disciplinary backgrounds, could help to make AL more cohesive and increase the level of mutual respect and understanding within the field.

\section{Bio Data}

Matthew W. Turner is an English language lecturer in the International Tourism Management Faculty at Toyo University. He holds an MA in applied linguistics and TESOL from the University of Leicester and is currently working towards a PhD at the University of Warwick. His professional interests include teacher development, reflective practice, continuing professional development, and support for learners with special educational needs. Matthew is the current coordinator of JALT's Teacher Development SIG. <turner@toyo.jp>

Matthew Y. Schaefer holds a Delta and received his MA degree in TESOL from Nagoya University of Foreign Studies. His experience includes teaching EFL in France, Italy, and Spain and academic management in the U.K. and Japan. He is currently a lecturer at Tokyo International University. His research interests include curriculum design, program evaluation, teacher education, and speaking assessment. <myschaefer1920@ gmail.com>

Robert J. Lowe is a lecturer in the Department of English Communication at Tokyo Kasei University. He holds an MA and a PhD in applied linguistics and is coauthor of Teaching English as a Lingua Franca: The Journey From EFL to ELF (DELTA Publishing, 2019). His professional interests include ideology in language education and qualitative methodology in applied linguistics research. <robert-l@tokyo-kasei.ac.jp>
Mehrasa Alizadeh is a specially appointed assistant professor at the Language Education Support Research Division, Cybermedia Center, Osaka University. Her main research interests include computer assisted language learning (CALL), online course development/quality assessment, and AR/VR applications in language teaching. $<$ mehrasa@cmc.osaka-u.ac.jp>

Dat Bao is a senior lecturer in Monash University, Australia. Previously he has worked with universities in the U.S.A., U.K., Thailand, and Singapore. His expertise includes curriculum design, intercultural communication, materials development, creative pedagogy, and visual pedagogy in language education. He is the author of Understanding Silence and Reticence: Ways of Participating in Second Language Acquisition (Bloomsbury) and Creativity and Innovations in ELT Material Development: Looking Beyond the Current Design (Multilingual Matters).<dat.bao@monash.edu>

Judith B. O'Loughlin has taught in K-12, adult education, and graduate university TESOL endorsement programs. She consulted and taught for U.S. federal and state grants to train ESL and special education teachers. As a consultant, her focus is on standards-based differentiated curriculum, collaborative teaching, and newcomers with interrupted education. She is the author of the Academic Language Accelerator (Oxford) and coauthor of Students With Interrupted Formal Education: Where They Are and What They Need (Corwin). <joeslteach@aol.com>

\section{References}

Alizadeh, M., Mehran, P., Koguchi, I., \& Takemura, H. (2017). Learning by design: Bringing poster carousels to life through augmented reality in a blended English course. In K. Borthwick, L. Bradley, \& S. Thouësny (Eds.), CALL in a climate of change: Adapting to turbulent global conditions-Short papers from EUROCALL 2017 (pp. 7-12). Dublin, Ireland: Research-publishing. net.

Barfield, A., \& Smith, R. (1999). Teacher-learner autonomy: The role of conference and workshop design. In Proceedings of the TDTR 4 Conference, September 2-4, 1999 (CD-ROM). Whitstable, Kent, England: IATEFL. Retrieved from https://warwick.ac.uk/fac/soc/al/people/smith/smith_r/ pre-2002/barfield__smith_1999.pdf

Capstick, T. (2018). Resilience. ELT Journal, 72(2), 210-13. https://doi.org/10.1093/elt/ccx068

Carducci, R., Kuntz, A. M, Gildersleeve, R., \& Pasque, P. A. (2011). The disruptive dialogue project: Crafting critical space in higher education. InterActions: UCLA Journal of Education and Information Studies, 7(2), 1-20. 
Clarke, M. (1994). The dysfunctions of the theory/practice discourse, TESOL Quarterly, 28(1), 9-26. https://doi.org/10.2307/3587196

Choi, S., \& Richards, K. (2017). Interdisciplinary discourse. London, England: Palgrave Macmillan.

Driver, P. [Cambridge University Press ELT]. (2018, April 19). A new perspective: Virtual reality and transmedia spherical video in teacher training [Video file]. Retrieved from https://www.youtube. com/watch?v=DXDCUTLi6WY

de Vries, B., \& Pieters, J. (2007). Knowledge sharing at conferences. Educational Research and Evaluation, 13(3), 237-247. https://doi.org/10.1080/13803610701626168

Graham, P., \& Kormanik, M. (2004). Bridging the conference gap: A challenge to enhance the research-practice dialogue. Human Resource Development International, 7(3), 391-393. https:// doi.org/10.1080/1367886042000245996

Grotberg, E. H. (1995). A guide to promoting resilience in children: Strengthening the human spirit. The Hague, the Netherlands: Bernard van Leer Foundation.

Hawkinson, E., Mehran, P., \& Alizadeh, M. (2017). Using MAVR to bring new dimensions to the classroom. The Language Teacher, 41(3), 30-32. Retrieved from http://jalt-publications.org/sites/ default/files/pdf-article/41.3tlt-wired.pdf

Lehr, J. L., McCallie, E., Davies, S. R., Caron, B. R., Gammon, B., \& Duensing, S. (2007). The value of "dialogue events" as sites of learning: An exploration of research and evaluation frameworks. International Journal of Science Education, 29(12), 1467-1487. https://doi. org/10.1080/09500690701494092

Lowe, R. J., Schaefer, M. Y., \& Turner, M. W. (2017). Podcasting and professional development: A guide for English language teachers. The Round. Available from http://the-round.com/resource/ podcasting-and-professional-development/

Maley, A. (2016). 'More research is needed'-A mantra too far? Humanizing Language Teaching, 18(3). Retrieved from https://www.tttjournal.co.uk/uploads/File/ttj_plus/Alan_Maley research_chapter.pdf

Mann, S. (2016). The research interview: Reflective practice and reflexivity in the research process. New York, NY: Palgrave Macmillan.

Medgyes, P. (2017). The (ir)relevance of academic research for the language teacher. ELT Journal, 71(4), 491-498. https://doi.org/10.1093/elt/ccx034

Schaefer, M. Y., Turner, M. W., \& Lowe, R. J. (2018). Global educators, local connections. In P. Clements, A. Krause, \& P. Bennett (Eds.), Language teaching in a global age: Shaping the classroom shaping the world (pp. 15-22). Tokyo: JALT. Retrieved from http://jalt-publications.org/sites/ default/files/pdf-article/jalt2017-pcp-003.pdf

Wells, G. (1999). Dialogic inquiry: Towards a sociocultural practice and theory of education. Cambridge, England: Cambridge University Press.

\section{Appendix A}

\section{Lists of Prepared Interview Questions}

These lists show the questions that were written in advance of each interview. During the interviews themselves the order of the questions was changed, some questions were skipped, and some follow-up questions were asked spontaneously. We direct readers to the podcast episodes listed in Appendix B to hear this process in action.

\section{Questions in Mehrasa Alizadeh's Interview}

1. I know from your conference biography that you studied and worked in Iran before arriving at your current teaching context in Osaka. Could you give us a summary of your career history to date?

2. At the conference today you are talking about the use of MAVR (mixed, augmented, and virtual realities) and their applications to the language classroom. But you are also interested in a range of issues related to computer-assisted language learning Could you talk about how you first became interested in the use of technology in language teaching?

3. Most young people, and perhaps many older people as well, spend a lot of their time engaging with the world online. How important do you think it is now, or will become in the future, for all language teachers to familiarize themselves with Internet-based aspects of our profession?

4. What are the main benefits of using MAVR in the classroom, for both the students and the teacher?

5. The conference theme for JALT this year is diversity and inclusion. What are some ways that MAVR can promote diversity and inclusion?

6. What are some of the most common challenges you hear people expressing about MAVR applications to the classroom? How do you respond to those challenges?

7. One of your research interests is online course design, development, and quality assessment. How do these aspects of considering an online course differ from those of a more traditional classroom-based course?

8. Do you see any connections between the use of technology in the classroom and creativity, which is an area that our next interviewee, Dat Bao, will be talking about.

9. What are some good entry points for teachers who are a bit scared of, or unsure about, using MAVR technology in the classroom? 
10. So far, we've focused on MAVR in terms of language learning. Are there any ways that it can be, or has been, applied to language teachers' professional development?

Questions in Dat Bao's Interview

1. Thank you for agreeing to take part in our forum today. Could I ask you to briefly introduce yourself and your research interests to our audience here today?

2. I'd first like to ask you about your interests and work in creativity. In your book Poetry for Education, you mention that for a number of different reasons, many students suffer from imagination problems. First, why do you think students may lack the ability or perhaps more the chance to use their imagination fully in the classroom, and how can tailored resources such as poetry help with this?

3. I noticed that you are also a painter and poet yourself. Growing up, I was always creative, and although I didn't go into a profession that is traditionally considered creative, I feel that I can channel my creativity through teaching. Generally speaking, do you think that teaching and education are considered to be a creative pursuit?

4. You cite research that indicates the benefits of creative education to introduce your collection of poems. Could tell us a little bit about what the research has found?

5. In your talk earlier, you introduced us to your research into a group of Japanese learners learning English in Melbourne, Australia. You described how you feel that their English has "woken up." How did creativity play a part in this?

6. You have written about the phenomenon of reticence and silence in the language learning classroom. In your book you set out to reposition and reframe related attitudes. Could you talk us through these terms in relation to our field?

7. Do you think that there are any links between reticence and silence in the classroom, and the extent to which creativity and imagination is nurtured and enacted?

\section{Questions in Judith B. O'Loughlin's Interview}

1. Can you start by telling us a little about yourself and how you became interested in the topic of resilience?

2. In your plenary you refer to a model of resilience that is called "I have, I can, I am." Could you explain this briefly?

3. How might resilience be an issue for foreign language learners?
4. In 2016, UNICEF identified three levels of influence on resilience: the community, the family, and the individual. How do you view the relationships between these three levels?

5. Resilience has recently been featured as a key concept in ELT Journal, and in the article the author Tony Capstick notes that "In ELT there has been a particular focus on building individual resilience, mirroring increasing concerns in mainstream general education about learners' mental health." Considering the three levels discussed earlier, do you think it is necessary for ELT professionals to move beyond the individual in terms of resilience building, and how might this be achieved?

6. Much of the research on the influence of resilience among language learners seems to have been focused on survivors of trauma or conflict such as refugees. How might building resilience be beneficial for learners from other (perhaps more typical) backgrounds?

7. How can teachers go about fostering resilience among students in the language classroom? What kinds of activities or approaches could they employ?

8. The idea of "resilience" in psychology has been criticised over the years, with some claiming that it shifts the onus of maintaining wellbeing onto the individual and thereby removing the responsibility of care from the wider society. Do you think there is any merit in this criticism?

\section{Appendix B}

Audio Recordings of Forum Interviews and Discussion

Interview with Mehrasa Alizadeh

Turner, M. W., Lowe, R. J., \& Schaefer M. Y. (Producers). (2019, January 3). TEFL Interviews 48: Mehrasa Alizadeh (JALT2018) [Audio podcast].

Retrieved from http://traffic.libsyn.com/teflology/Mehrasa_Alizadeh.m4a

Interview with Dat Bao

Turner, M. W., Lowe, R. J., \& Schaefer M. Y. (Producers). (2019, January 9). TEFL Interviews 49: Dat Bao (JALT2018) [Audio podcast].

Retrieved from http://traffic.libsyn.com/teflology/Dat_Bao.m4a 
Interview with Judith B. O'Loughlin

Turner, M. W., Lowe, R. J., \& Schaefer M. Y. (Producers). (2019, January 16). TEFL

Interviews 50: Judith B. O'Loughlin (JALT2018) [Audio podcast].

Retrieved from http://traffic.libsyn.com/teflology/Judith_B._OLoughlin.m4a

Interviewee Interaction

Turner, M. W., Lowe, R. J., \& Schaefer M. Y. (Producers). (2019, January 23). TEFL

Interviews 51: Forum Discussion (JALT2018) [Audio podcast].

Retrieved from http://traffic.libsyn.com/teflology/Forum_18.m4a 